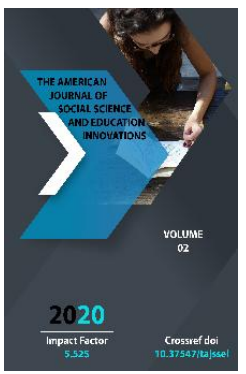

\title{
Classification Of Sentences In Comparison Content With The Participation In Prefix比 Bǐ In Chinese Language
}

\author{
Adiba Botir Qizi Makhamadtoirova \\ Lecturer, Department Of “Chinese Language And Literature”, Tashkent State University Of \\ Oriental Studies, Uzbekistan
}

Journal Website: http://usajournalshub.c om/index,php/tajssei

\section{Copyright: Original} content from this work may be used under the terms of the creative commons attributes 4.0 licence.

\section{ABSTRACT}

In modern Chinese, there are many ways to express differences or similarities between things and events, situations and qualities, and also levels, to add they are mainly used to compare differences in high or low a situation. At the same time, it helps to make the speech stylistically brief and fluent. The words in the context of comparison are expressed in Chinese by the term 比较句 bijiào jù. If we look at the analysis of this word, 比较 bijjiào compares 句 jù which gives meaning of the sentence. There is no equivalent of the words analogy in Chinese language, into Uzbek, all of which are called compression 比较句 bijiào jù.

In Chinese language there are many types of expressions of differences and similarities between things and events, states and qualities, and levels, and the prefix 比 bi is used to express the difference, high, or low of qualities and levels. It is mainly used to compare differences between two people, or two objects, and also two levels of situations. This article is devoted to the classification of sentences with the presence of the prefix 比 bǐ, the expression of sentences with the presence of the prefix 比 bì, the specific construction models of these constructions, the functions of the sentence.

\section{KEYWORDS}

Compare, comparison, analogy, comparative degree, prefix, object of comparison, subject of comparison, construction. 


\section{INTRODUCTION}

In modern Chinese, sentences in the context of comparison are divided into two major groups:

1) comparative methods of expressing the difference in adjective and degree, high or low; 2) comparative methods of expressing the similarity of the level of an object, event and situation [4.123].

According to the uzbek linguist G.A.Abdurahmanov's comments on comparative statements, we can divide such statements into two main groups:

- systems with clear comparative content;

- systems with simulation content [1, 233].

Based on the views of the uzbek linguist G.A.Abdurahmanov, russian linguist V.I Gorelov and Chinese linguist 刘月花 Liú Yuèhuā, we divide them into two large groups of comparative sentences in Chinese.

\section{MATERIALS AND METHODS}

The first group is a group of constructions that have a perfect comparative, comparative content, representing the difference between adjective and degree, high or low, and in this group we include the following constructions with participation in:

- 比 bì; 一天比一天yìtiān bì yìtiān, 一年比一年yìnián bì yìnián, 一次比一次yícì bì yícì ; 不如bùrú, 不比bùbǐ,没有meiyou; 越来越yuèláiyuè

The second group is a group of constructions with analogous meanings, representing the equality of things, events and situations, and in this group we include the following constructions with participation in:

- 跟 gēn.... 一样yīyàng; 跟gēn.... 相同xiāngtóng; 跟gēn.... 相似xiāngs̀̀; 跟gēn....近似jìnsì; 跟gēn....类似lèisì and their negatives verb constructions 有yǒu.

We analyze the specific construction models of constructions with the participation in the prefix 比 bi and the functions in speech based on the opinion of the Chinese linguist 刘月花Liú Yuèhuā. It is divided into 3 parts based on the functions of the sentence:

1) The classification of the sentence with the presence of the prefix 比bi.

2) The issue of the shortening of the sentences with the presence of the prefix 比bì.

3) In the sentence with prefix 比bì it is devoted to the issues 更gèng, 还hái, 再zài.

\section{RESULTS AND DISCUSSION}

The prefix 比bi is used to express between high and low in adjective and degree and is mainly used to compare the differences in the levels of two people, two objects, or two states.When the object of comparison is being compared with the prefix 比bǐ, the predicate represents the result of the comparison. In this case based on the location, the object or situation being compared comes first, then the prefix 比bì, then the object being compared, and then the result of the comparison. Semantically, in the main structure the adverbial modifier takes place 
between the subject predicate and 比bi acts as adverbial modifier. When differences in adjective and degree is compared with prexift比b̌̀, it is made as follows $[6,466]$.

The first construction looks like this:

$[A$ (Subject) + 比 B (adverbial modifier) + predicate].

In this form in the function of the predicate, adjectives, verbs, adjective phrase, adverbs, possessives and adverbs can be used. For example:

\section{1. 这坐山比那坐山高。}

Zhè zuò shān bǐ nàzuò shān gāo.

This mountain is higher than that mountain.

In this sentence the prefix比bi with comparision meaning is used between two subjects, the adjective high 高gāo performs the function of the predicate and it is used at the end of the sentence.

2. 刘继武激动地说:

“爷爷,你比我更懂得枪的用处,你比我更 喜欢这支枪”。

Liú Jìwǔ jīdòngdì shuō: “Yéye,nǐ bǐ wǒ gèng dǒngdé qiāngde yòngchu, nǐ bǐ wǒ gèng xǐhuan zhè zhī qiāng".

Liu Jivu said exitedly: "Grandpa, you know how to use a gun better than I do, and you love that gun more than me".

\section{3. 我父亲比我母亲身体好。}

Wǒ fùqīn bǐ wǒ mǔqīn shēntǐ hăo.

My father's health is better than my mother's.

In this sentence the prefix比bi with comparision meaning is used between two subjects, the adjective "good" 好hăo performs the function of the predicate and it is used at the end of the sentence.

Sometimes the adjective comes after verb, subject predicate phrases, the exact degree comes together with object expressing the quantity or adverbial modifier, and serves to express the difference. It is reflected in several cases.

1) The predicate is consists of the adjective. If after the adjective 一点儿yìdiánér, 一些yìxiē, 多了duōle, 得多déduō or quantity objects can be followed [7, 121]. For example:

\section{1. 这座山比那座山高一些。}

Zhè zuò shān bǐ nàzuò shān gāo yìxiē.

This mountain is a bit higher than that mountain.

In this sentence the prefix 比bì with comparision meaning is used between two subjects, the adjective 高gāo performs the function of the predicate and it is used at the end of the sentence quantity object is used.

2. 这棵树比那棵树粗一点儿。

Zhè kē shù bǐ nà kē shù cū yìdiánr.

This tree is a little thicker than that tree.

3.

虽然他比我只大一岁, 可是什么事情我都听他 的。

Suīrán tā bǐwǒ zhǐ dà yīsù̀, kěshì shénme shìqíng wǒ dōu tīng tāde.

Even though, he is only one year older than me, I listen to him in any situation.

\section{4. 我比他得多, 自然头发也比他白得多。}


Wǒ bǐ tādé duō, zìrán tóufa yě bǐ tā báidéduō.

I am older than her, of course my grey hair is more than hers.

\section{5. 往后的日子比这好一百倍。}

Wănghòude rìzi bǐ zhè hăo yī bǎibèi 。

The previous days were a hundred times better than they are now.

\section{A:这块布比那块布只长一公尺吗?}

Zhè kuài bù bǐ nà kuài bù zhǐ cháng yī gōngchǐ ma?

This piece of material is one meter longer than that one.

$\mathrm{B}:$ 不,长多了。

Bú, cháng duōle.

No, it is longer than that.

(2) The predicate 有yǒu + is consists of the a passive noun. In this case the verb object phrase subordinates to subject, equals to the adjective and may bring such objects 多了 duōle, 得多déduō after them. But can not be used with the degree and quantity objects $[3,170]$. For example:

\section{1. 那位老中医比我们有经验得多,} 而且下药十分谨慎。

Nàwèi lăozhōngyī bǐ wǒmen yǒu jīngyàn déduō, érqiě xiàyào shífēn jǐnshèn.

Although, that doctor is more experienced than us, he is very careful while prescribing medications.

2. 小王比他师傅有办法多了, 办事也很灵活。

Xiăowáng bǐ tā shîfu yǒu bànfă duōle, bànshì yě hěn línhuó.
Xiăowáng has a lot of methods compared to that coach, and she is very active when she works.

In the sentence 一点儿yìdiánr, 一些yìxiē is usually used in front of the passive noun, acts as a conditional. For example:

1.张老师的看法比他的有些道理。

Zhāng lǎoshī de kànfă bǐ tā de yǒuxiē dàolǐ.

Zhang teacher's opinion is closer to the reality than his.

\section{2. 他比他哥哥有点儿眼光。}

Tā bǐ tā gēge yóu diánér yănguāng.

$\mathrm{He}$ is a bit clever than his brother.

(3) The predicate is abstract, thus consists of the abstract verb. Sometimes after the predicate objects such as - 点儿yìdiánr, 一些yìxiē, 得多déduō can be followed [7, 340]. For example:

\section{1. 他对这儿的情况比我了解得多。}

Tã duì zhérde qíngkuàng bǐ wǒ liáojiě dé duō.

He understands the situation better than I do.

\section{2.} 姐妹两个都喜欢跳舞, 姐姐比妹妹更喜欢一些。

Jiěmèi liănggè dōu xǐhuan tiàowǔ, jiějie bǐ mèimei gèng xǐhuan yìxiē.

Both sisters love to dance, and elder sister loves it more than her younger one.

(4) When the verb is used as the predicate, the conditionals 早zăo, 晚wăn, 先xiān, 后hòu, 难nán, 好hăo are used before it. After the verb the objects expressing activities are added. For example: 


\section{1.我家什么人也没有,就我老杆一个,}

\section{再苦也比你的好对付。}

Wǒ jiā shénme rén yě méiyǒu,jiù wǒ lăogăn yígè, zài kǔ yě bǐ nǐde hăo duifu.

There is no one in our house, only myself is solitary, and I am more resilient than you when I am in pain.

2.虽然老纪已比我先认出了对方,

她紧抿着的嘴角有些颤动.

Suīrán lǎojì yǐ bǐ wǒ xiān rènchūle duìfāng,tā jǐnmǐnzhede zuíjiǎoyǒuxiē chàndòng.

Even though, Laoji knew her interlocutor better than me, the corner her tightly closed mouth was trembling.

The adverbs coming together with verbs , serves only to make meanings. It can bring 一点儿yì diánr,一些yìxiē, 多了duōle, 得多déduō after themselves. Also, it is also possible to come with definite quantity degree difference or complement.

For example:

1. 这些汉字比那些汉子难写一些。

Zhèxiē hànzì bǐ nàxiē hànzi nán xiě yìxiē.

These hieroglyphs are a little harder to write than those hieroglyphs.

\section{2.他今天比我早来十分钟。}

Tā jīntiān bǐ wǒ zăo lái shí fēnzhōng.

Today he came 10 minutes earlier than me.

4.小刘比我们多吃了很多南瓜粥。

Xiǎoliú bǐ wǒmen duō chīle hěnduō nánguā zhōu.

Xiao Liu ate more pumpkin porridge than I did.
(5) If the predicate consists of the verb, after that the word belonging to adverb is used. Furthermore, after the adverb the followings 一点儿yìdiánr, 一些yìxiē, 多了duōle, 得多deduo may come together. For example:

1. 他比我睡得晚一点儿。

Tã bǐwǒ shuìdé wăn yìdiánér.

He sleeps later than me.

2. 他睡得比我晚得多。

Tā shuìdé bǐwǒ wăn dé duō.

He sleeps a bit later than me.

\section{3.弟弟看书比我看的快多了。}

Dìdi kànshū bǐwǒ kànde kuài duōle.

My brother reads faster than I do.

In a way to express this kind of comparison the prefix “比....." can be used before the verb (1-example); can be used after the verb (2example). If the verb comes along with object, can also be placed before the repeated verb. Also, after the adjective that comes as a conditional complement, the words related to the quantity that represent a clear difference can not be used. For example: 他比我睡得晚半个小时Tā bǐwǒ shuidé wăn bàn gè xiăoshí can not be said.

(6) The predicate is consists of "modal verb + verb". Usually in such combinations modal verbs 能néng, 会huì are used. There also be semantically flexible 一些yìxiē, 多了duōle complements may be used. For example:

1. 妹妹比姐姐能吃苦。

Mèimei bǐ jiějie néng chīkǔ.

The younger sister is more resilient than her elder sister. 


\section{2. 他比我会说话多了。}

Tā bǐwǒ huì shuōhuà duōle.

She can talk more than I can.

3. 我们俩都不大会写诗,老张比我们能写一些。

Wǒmen liăng dōubú dàhuì xiěshī, Lǎozhāng bǐ wǒmen néng xiě yìxiē.

Neither of us can write a good poetry, Lao Jang can write better than us.

It is important to note to unite that phrases of these types of verbs凝结很紧ningjie henjin is very close, usually represents the general meaning of a word. Modal verbs do not change their position, and no words or phrases can be added to the verb that comes after them. In other comparisons modal verbs are used before 比bǐ $[8,180]$. For example, in such 她能比你来得早吗? Tā néng bǐ nǐ láidé zăo ma? sentences, the modal verb applies to all subsequent words.

One more modal verb can be used before 比bi in comparative sentences relating to hereto group. For example, 妹妹会姐姐能吃苦的mèimei huì jiějie néng chī kǔde; 她应该比我会说话tā yīnggāi bǐ wǒhuì shuōhuà?

Here modal verbs 会huì and 应该yīnggāi are used in the same way as 能néng in the above sentence.

(7) When the predicate is consists of verbs meaning increase, decrease, rise, drop, the word group belonging to the number which come after these verbs acts as the noun phrase complement. For example:
1. 今年这个村粮食亩产比几年前增加了二百

多公斤。

Jīnnián zhège cūn liángshi mǔchăn bǐ jǐ niánqián zēngjiāle èrbǎi duō gōngjīn.

This year the field of the village growing the wheat has expanded by 300 hectare compared to the last year.

2. 我的体重比上个月减轻了, 而且减轻了很多。

Wǒde tǐzhòng bǐ shàng gèyuè jiănqīng le, érqiě jiănqīng le hěnduō.

I have lost a weight compared last month, I lost much more weight.

In the second sentence the noun 很多hěnduō should be considered as a characteristic phrase. Because the number which is represented means a lot $[9,102]$.

The second structure looks like this:

[Subject+ A 比B+(状语)+ predicate)

In such expressions, it is always used to express the difference between the different objects in the same object or time. For example:

1. 他现在比以前进步多了。

Tā xiànzài bǐ yǐqián jìnbù duō le.

He is more improved than before.

2. 这孩子在幼儿园比在家表现好。

Zhè háizi zài yòuéryuán bǐ zàijiā biǎoxiàn hăo.

This child behaves better at home than in kindergarten.

3. 你的发音这次比上次好多了。 
Nǐde fāyīn zhècì bǐ shàngcì hăo duō le

Your pronunciation is much better this time than before.

While making up sentences when we use 一年比一年yìnián bì yìnián “year to year", 一天比一天yìtiān bì yìtiān “day to day” expressions, they come as the complement in the sentence, indicates that the degree difference is slowly changing.

\section{For example:}

\section{1. 他身体一天比一天好了。}

Tā shēntǐ yìtiān bǐ yìtiān hăole .

His health is getting better day by day.

\section{2. 发行数量一年比一年增加。}

Fā xíng shùliàng yìnián bǐ yìnián zēngjiā.

The distribution is increasing year by year.

\section{3. 他考试的成绩一次比一次好。}

Tā kăoshì de chéngjì yícì bǐ yī cì hăo .

His exam results are getting better and better.

In Chinese if the ages of two people are compared, the age is expressed with 岁suì, not 年nián. For example, “I am two years older than you, he is one year younger than you" is translated in Chinese as following [10, 68]:

\section{我比你大两岁,他比你小ー岁。}

Wǒ bǐ nǐ dà liăng suì, tā bǐ nǐ xiăo yí suì.

It can't be translated as following.

However, when expressing the age difference elder and younger the predicate is expressed with 大dà, 小xiăo verbs. For example:
1. 我比你大。她比你小。

Wǒ bǐ nǐ dà. Tã bǐ nǐ xiăo.

I am older than you. He is younger than you.

( 我二十岁一, 你二十岁, 她十九岁; 等等)

( I am 21 years old, you are 20, he is 19 and etc.)

2. 他比他弟弟大得多, 弟弟比他小得多。

Tã bǐ tā dìdi dà dé duō, dìdi bǐ tā xiăo dé duō.

(他二十岁, 他弟弟十二岁)

( $\mathrm{He}$ is 20 years old, his brother is 12 years old.) 姐姐比哥哥大一点儿, 哥哥比姐姐小一点儿。

Jiě jie bǐ gēge dà yī dián ér, gēge bǐ jiějie xiǎo yìdiánér.

My sister is a bit bigger than my brother, my brother is a bit smaller than my sister.

(姐姐二十二岁,哥哥二十岁)

(His sister is 22 years old and brother is 20 and etc.)

In the example above we have grammatically classified the constructions that represent the comparative degree with the help of the prefix 比bì. Now we look at the other grammatical features.

The abbreviation of some parts of the比bì sentences

Usually the words before and after the prefix比bi have the same properties and structure. If there is a similarity between the words before or after the prefix比bì one can be omitted (usually the part after比bi is omitted). A change in a word as a result of a drop of a word does not affect its meaning. Abbreviations like these help keep the 
sentence simple and fluent. There are several ways to do this, which we will discuss below.

1. The declension of the main word (中心语 zhōngxīn yǔ sentence core. In the sentence, the main meaning is the word, and the sentence revolves around the same word.). If the noun $A$ and $B$, "which came before and after the比 bi prepositions, is in the form of the pronoun identifier+的+ the main word is in the form of the noun suffix", if the central parts are also the same, then in most cases the compoundonent that comes after比 bì, that is, the main word " $\mathrm{B}$ " can fall. Just enough to keep the的 de from attaching with the handle [7, 350]. For example:

\section{1. 小英的布娃娃比他的(布娃娃)好看}

Xiǎo Yīng de bùwáwa bǐ tāde(bù wá wa)hăokàn.

Xiao Ying's fabric toy is more beautiful than his fabric toy.

\section{2. 老虎的爪子比耗子的(爪子)大。}

Láo hǔ de zhuǎ zi bǐ hào zi de( zhuă zi) dà.

A real silk dress is more expensive than her dacron (from her dacron shirt).

\section{3. 真丝的衬衫比他的确良的(衬衫)贵。}

Zhēnsīde chènshān bǐtādíquè liángde (chènshān )gù̀.

The tiger's paws are bigger than the rat's.

的 de cannot be omitted in these statements. If 的 de is omitted, the translation will change $[7,208]$. For example:

小英的布娃娃比他好看。

1. Xiǎo yīng de bù wá wa bǐ tā hăo kàn.
Xiao Ying's fabric toy is more beautiful than that.

\section{2. 老虎的爪子比耗子大。}

Láo hǔ de zhuă zi bǐ hào zi dà.

The tiger's paws are larger than those of a rat.

\section{3. 真丝的祄衫比的确良贵。}

Zhēnsī de chènshān bǐ díquè liángguì.

A real silk shirt is more expensive than a dacron.

Because the appearance of Xiao Ying's soft toy is comparable to that of "him"; The size of a "tiger's claw" and a "mouse's" body can be compared, and the price of a "real silk shirt" and a "dacron" can be compared. This means that if the horse falls after the 比 bi prefixes in the comparative sentence, the drop of 的 de when the rhyme comes with the determiner cannot be omitted, either because the meaning of the sentence has changed [8, 199].

The abbreviation method cannot be used when the defining keyword refers to kinship. For example:

\section{1. 这些孩子的父母都比你们的父母年轻。}

Zhèxiē háizi de fùmǔ dōu bǐ nǐmen de fùmǔ niánqing.

The parents of these children are all younger than your parents.

\section{2. 你的弟弟比我的弟弟淘气。}

Nǐ de dìdi bǐ wǒ de dìdi táoqì.

Your brother is smarter than me.

\section{3. 他们的领导比我们的领导能体谅不清。}

Tāmende língdǎo bǐwǒ mende língdǎo néng tǐliàng bùqing. 
Their leader is more nationalistic than our leader.

2. The omission of the main word and the auxiliary word 的. Such statements, in turn, are subject to certain grammatical rules, and we can observe several types of them. They are:

1) If $A$ and $B$ are involved in such sentences, then $B$ cannot have a definite article, which means that in addition to the main word, the auxiliary word may also be omitted [9]. That doesn't change the meaning. For example:

1. 他的字比我(的)(字) 潦草。

Tã de zì bǐ wǒ (de)(zì)liáocăo.

Her hieroglyph is more beautiful than mine.

\section{2. 王先生的行李比你(的) (行李) 多。}

Wáng xiānshēng de xíngli bǐ nì(de) (xíngli) duō.

Janob Vanning jamadoni senikidan ko'p.

Mr. Van's suitcase is bigger than yours.

2) When A, B are used to compare time sequences or different spaces, 的 de can usually be omitted. It is enough to keep the identifier of time and space [4, 1986]. For example:

\section{1. 今年他的收成比去年(的) (收成)好多了。}

Jīnnián tā de shōucheng bì qùnián de shōucheng hăoduō le.

This year's harvest is much higher than last year's.

2. 老李这个月的收入比上个月(的)(收入)少。

Lăolǐ zhège yuè de shōurù bǐ shànggè yuè de shōurù shǎo.
Lao Li's income this month is less than the previous month.

\section{3. 我们家北京的亲戚比天津的亲戚多。}

Wǒmen jiā Běijing de qīnqi bǐ Tiānjīn de qinnqi duō.

We have more relatives in Beijing than in Tianjin.

3) If the key words of A and B are a person or thing and an event, it is better to omit it together with 的 de. For example:

1. 南方的夏天比北方(的夏天)热。

Nánfāng de xiàtiān bǐ běifāng (de xiàtiān) rè.

Summer in the south is warmer than in the north.

\section{2. 十年前的我要比现在(的我)更糊涂。}

Shínián qián de wǒ yào bǐ xiànzài (de wǒ) gèng hútu.

Ten years ago I was more confused than I am now.

3. Fall of the detector. In the equestrian phrase $A$ and $B$, if the determiner is the same and the keyword is different, then the determiner in the part following the 11 preceding auxiliaries may be omitted [6.201]. For example:

\section{1. 我看他的法语说的比英语流利。}

Wǒ kàn tā de fáyǔ shuō de bǐ yīngyǔ liúlì.

I think he speaks French more fluently than English.

\section{2. 他的小说比诗歌写得好。}

Tāde xiǎoshuō bǐ shīgē xiědéhăo.

His stories are better written than his poems. 
4. The omission of a similar part between the determiner and the keyword. If the descriptive and key words are the same in A and $B 2$ noun phrases, then we can abbreviate the preceding or following similar parts of prefix 比bǐ $[10,96]$. For example:

1.

你的口头表达能力比(你的)笔头(表达能力)好

○

Nǐde kǒutóu biǎodá nénglì bǐ(nǐ de ) bǐtóu( biǎo dá néng lì ) hăo.

Your speech is better than your ability to express it in writing.

2.

我们学英语的时间比(我们)学法语(的时间)长

Wǒmen xué yīngyǔ de shíjiān bǐ ( wǒ men ) xué fáyǔ ( de shí jiān ) cháng.

We spend more time learning English than we do learning French.

3. 他们 (前进的脚步) 比我们前进的脚步快。

Tāmen (qiánjìn de jiǎobù) bǐ wǒmen qiánjìn de jiăobùkuài.

We are faster than them.

5. The possessive-cut has in simple sentences or the cut off is dropped. If there is a simple sentence consisting of a cut with components $A$ and $B$, and the cuts in the possessive participles are the same, we can shorten the components before or after 比bì. If the owners of the cut-offs are the same, then we can reduce it to only after 比 bǐ [7, 210]. For example:

1. 他睡觉比我(睡觉)早。
Tã shuijiào bǐ wǒ ( shuì jiào ) zăo.

He goes to bed earlier than me.

2.我(吃饭)比他吃饭香。

Wǒ ( chīfàn ) bǐ tā chīfàn xiāng.

Her food is delicious from my meal.

\section{3. 我学汉语比(我)学日语快。}

Wǒ xué hànyǔ bǐ (wǒ) xué rìyǔ kuài.

Learning Chinese is faster than learning Japanese.

\section{4. 我住在北京比(我)住在广州好。}

Wǒ zhù zài Běijīng bǐ (wǒ) zhù zài Guăngzhōu hăo.

I live better in Beijing than Guang Joo.

Sentences 1-2 in these examples can be changed as follows: 他比我睡觉早tā bì wǒ shuì jiào zăo, 我吃饭比他先wǒ chī fàn bì tā xiāng. Sentences 3-4 cannot be changed. That is, 学汉语比我学日语快 xué hànyǔ bǐ wǒ xué rìyǔ kuài, 住在北京比我住在广州好 zhù zài Běijīng bǐ( wǒ )zhù zài cannot be said. Abbreviations cannot be used if both the possessive and the participle are in the same word and the participle is not the same. For example:

你吃盐比他吃米多。

Nĩ chī yán bǐtā chīmì duō.

You eat more salt than you eat rice.

6. When "A 比B" occurs, the front part A of the 比bì front auxiliaries falls. The words "A 比B" compare the state of the same event at different times and in different places. Part $A$ can be abbreviated if the preceding part of 
比bǐ prefixes means 现在 (now), 当时 (then), 在这里 (here). For example:

1. 微风起来, 吹动她的短发, 确乎比去年白得多了 。(现在)

Wēi fēng qǔlái,chuīdòng tāde duănfā,quèhū bǐ qùnián bái dé duōle. (xiànzài)

The wind was blowing and her short hair was fluttering, and it was really much whiter than last year. (now)

2. 我的身体比前好多了。(现在)

Wǒ de shēntǐ bǐ qián hăo duō le .(xiànzài) I am much healthier than before. (now)

3. 今天我们比第次谈得多。

Jīntiān wǒmen bǐ dìcì tán dé duō.

We talked more today than we did the first time.

4. 这几个孩子都比在那里听话。(在这儿)

Zhè jǐ gè háizi dōu bǐ zài nà lĩ tīnghuà. (zài zhèr )

These guys are smarter than they were there. (here)

7. If both $A$ and $B$ are simple verbs or adjectives, the word will not fall. If both parts $A$ and $B$ are all verb conjunctions or adjective conjunctions and consist of the same components, then they are not abbreviated in most cases [7, 432]. For example:

1. 长一点比短一点好。

Cháng yìdiăn bǐ duăn yìdiǎn hăo.

A little length is better than a little short.

\section{2. 有文化比没有文化好。}

Yǒu wénhuà bǐ méiyǒu wénhuà hăo.

The presence of culture is better than the absence of culture.

In the case of the above example, or when the situation in the language is understandable. We can also drop the component before the 比 bǐ prefixes [14, 214].

The peculiarities of 更gèng, 还hái, 再zài adverbs

In comparative meaning sentences the adverbs such as更gèng,还hái, 再zài are used before compared predicate, it serves to express the degree of $A$ which is one step higher. For example:

\section{1. 那里的情况他比我更了解一些。}

Nà lĩ de qíngkuàng tā bǐ wǒ gèng liáojiě yìxiē.

He knows the situation there better than me

\section{2.他的话比你的更有说服力。}

Tã de huà bǐ nǐ de gèng yǒu shuōfúlì.

His words are more convincing than yours.

\section{3.他比你更会安排时间。}

Tā bǐ nǐ gèng huì ānpái shíjiān.

His Chinese is better than yours. We can see from above examples that one syllableadjective 更gèng, 还hái, 再zài can be used before verb and phrasal verbs. The verb may be used in front of word combination (有+ object, modal verb+verb form) $(2,3)$, also after the adjective or verbs 一点儿yì diánr, 一些yìxiē. 
If the adjective comes after the verb 多了duōle or if there is a quantity object then before it, usually the degree expression adverbs 更gèng, 还hái, 再zài are not used. For example:

1. 今年来华留学生的数目比去年增加了两倍多 ○ Jīnnián láihuá liúxuéshēng de shùmù bì qunián zēng jiāle liangbèi duō.

The number of international students has doubled this year compared to last year.

2. 一个小时他比我多看了两页书。

Yí gè xiǎoshí tā bǐ wǒ duō kànle liǎngyèshū.

He read two more pages than I did.

Below we will see the differences of using adverbs in comparative sentences (with the presence of比bǐ) 更gèn, 还hái, 再zài.

“A 比bǐ $B$ 更gèng...” figure $B$ has a define degree, but $A$ represents one step higher than this degree but there is no any specific emotional color in the whole sentence.

“A 比bǐ B 还hái..." figure B indicates that it is sufficient, thus to the extent that it satisfies the speaker (it may be unsatisfactory) also, in the form of “A 比bǐ $B$ 还hái..." has a feature to show the degree higher than "A 比bì $B$ 更gèng...” form.

“A 比 B 再zài..." form is usually used in hypotheses, hypothetic sentences, interrogative and negative sentencess [13, 324]. We will observe their difference in the following examples:
1.

这种帽子好,那种帽子比这种更好。(表示程度 )

Zhèzhǒng màozi hăo,nàzhǒng màozi bǐ zhèzhǒng gèng hăo.(biăoshì chéngdù )

2. 我觉得这种帽子够好了, 可是那种帽子比 这种还好。

(强调程度,有感情色彩)

Wǒ juédé zhèzhǒng màozi gòu hăo le, kěshì nàzhǒng màozi bǐ zhèzhǒng hái hăo. (qiángdiào chéngdù, yǒu gănqíng sècǎi)

3. 那种帽子比这种帽子再好, 我也不买。(假

设)

Nàzhǒng màozi bǐ zhèzhǒng màozi zài hăo,wǒ yě bùmăi. (jiăshè )

4. 那种帽子不会比这种再好了。(未成事实) Nàzhǒng màozi búhuì bǐ zhèzhǒng zài hăole. (wèichéng shìshí)

\section{5. 还有比这种帽子再好的吗? (疑问)}

Háiyǒu bǐ zhèzhǒng màozi zài hăo de ma? (yíwèn)

\section{6. 没有这种再好的了。(否定)}

Méi yǒu zhè zhǒng zài hăo de le. (fǒu dìng).

更gèng, 还hái, 再zài adverbs usually come before the predicate of comparison, thus after 比bì, and it is observed that adverbs as 更gèng and 再zài can be used before 比bì. 
The results of the article analysis led to the following conclusions:

- Comparative statements are used to identify similarities or differences between two or more objects, as well as to express the high, low, or equal degrees of comparison between them. Such expressions serve to enhance the meaning and color of the speech, making the speaker's speech clear, concise, and understandable to the listener.

- The purpose of comparing a particular event, phenomenon, sign, or feature is to identify the differences between them, or to contrast them, to show that they are incompatible. Such expressions are present in almost all languages of the world, but their structure, the laws of formation are characterized by certain specific aspects in each language.

- In modern Chinese, comparisons are used to compare how high or low the differences between words, things and events, situations and qualities, and levels are. Helps to make the speech stylistically concise and fluent. In the Uzbek language, the expression of the comparative base is mainly two types: the comparative base is expressed by a word in the adjective category, the comparative base is expressed by a word in the verb category, while the Chinese comparative base is represented not only by an adjective, a verb, but also a noun. The account is also represented by words.

- In modern Chinese, comparative sentences are divided into two major groups. The first group is the comparison methods that represent the difference in quality and level, high or low. The second group is the methods of comparison, which represent the similarity of the levels of things, events and situations. The first group, which is clearly comparative, context of comparison constructions with participation in : the prefix 比 bǐ, 不如, 不比, 没有, 越来越. The second group which has the analogue meaning with participation in : the prefix 跟gēn and verbs (跟.... 一样,跟.... 相同; 跟.... 相似; 跟....近似; 跟....类似) 有.

- The prefix 比is used to denote the difference, high or low, between qualities and levels, and is mainly used to compare the difference between the levels of two people, two objects, or two states. In such sentences it is not possible to use degree adverbs like 很, 非常, 极. If there is a big difference then can be expressed in “比...得多” yoki “比...多了” forms. But these two constructions cannot be used together. Degree and quantity complements cannot be used in the same sentence. In this case, object degree is dropped, the adjective makes up conditional, and is used before the verb.

- If 更, 还, 再degree adverbs come before predicate in the sentences with the prefix 比, it means that the degree of A became one more step higher. These degree adjectives have their own characteristics: the form “A 比B 更....." that $B$ has the define degree, and $A$ is one step higher than this degree. There is no emotional color in such words. "A 比B 还....." the form $B$ represents the degree to which the speaker is satisfied (it can be also unsatisfied), also, “A 比 B 还.....” forms have a higher degree of reinforcement than “A 比 B 更....." forms. “A 比 B 再.....” forms are usually used in hypotheses, hypothetic sentences, negative and interrogative sentences. 


\section{REFERENCE}

1. Abdurahmonov G.A., Shoabdurahmonov. Sh.Sh., Hojiev A.P. (1976) Uzbek grammar. II. Syntax. - Tashkent: Fan. - p. 450 p. (In Uzbek)

2. Gorelov V.I. (1982) Grammar of the Chinese language. - Moscow: Enlightenment. - p. 278 p. (In Russian)

3. Dragunov A.A. (1962). The grammar system of modern Chinese. - Leningrad. p. 250. (In Russian)

4. Zadoenko TK, Juan Shuin. (1986) The basics of the Chinese language. - Moscow. Nauka. -p. 245. (In Russian)

5. Morozova M.I. (1977) Logic and syntax of comparison. Grammar and norm. Moscow: Nauka. -p. 280. (In Russian)

6. Liu Yuehua waiting. (2001) Practical Modern Chinese Grammar. - Beijing: Commercial Press. - p. 840. (In Chinese)

7. Li Dejin, Cheng Meizhen. (2008) Practical Chinese for Foreigners. - Beijing: Beijing Language and Culture University Press. p. 652. (In Chinese)

8. Dai Xuemei, Zhang Ruoying. (1999) 300 Practical Chinese Grammar. - Beijing: New World Publishing. - p. 240. (In Chinese)

9. Ding Shengshu. (1996) Modern Chinese Grammar Speech. - Beijing: Commercial Press. - p. 120. (In Chinese)

10. Liu Haobo. (2013) A Syntactic Analysis of the $\mathrm{Bi}$ Comparative Construction. Sichuan: Sichuan International Studies University Master Degree Thesis. - p. 78. (In Chinese)

11. Ma Zhen. (1986) A Tentative Study of the Substitution Rule of Comparison Items of
Bibi Sentences. Chinese Language. - pp. 69. (In Chinese)

12. Shang Ping. (2006) A Review of Comparative Sentence System Research. Language and Character Applications. pp. 3-5. (In Chinese)

13. 苗东霞编煮. (2010) HSK 考前强化语法. -Beijing: Central Compilation and Translation Press. - pp. 475页.

14. Yang Jie, Du Xin. (2012). 新HSK模拟题集. (4/5). - Beijing: Central Compilation and Translation Press. - pp. 414. 